\title{
THE INSULINOTROPIC EFFECT OF THIAZOLIDINEDIONE DERIVATIVES IN TYPE II DIABETIC MODEL, RIN-5F CELLS, AND ITS ACTION ON CULTURED HUMAN LUNG FIBROBLAST SHOWS OXYGEN FREE-RADICAL SCAVENGING ACTIVITY
}

\author{
REKHA $S^{1 *}$, KALPANA DIVEKAR ${ }^{1}$, CHANDRASHEKHARA $S^{2}$
}

${ }^{1}$ Department of Pharmaceutical Chemistry, College of Pharmaceutical Sciences, Dayananda Sagar University, Bengaluru, Karnataka, India. ${ }^{2}$ Department of Pharmaceutics, Dr. Ravi Patil College of Pharmacy, Belgaum, Karnataka, India. Email: rekha.maheshh@gmail.com

Received: 15 January 2021, Revised and Accepted: 04 June 2021

ABSTRACT

Objective: Diabetes mellitus is a persistent disorder caused by deficiency in insulin production. Oxidative stress plays an important role in physiopathology of diabetes. The present research determined the antidiabetic and antioxidant effects of 5-naphthalidin thiazolidinediones derivatives.

Methods: Both in vitro and in vivo experiments were carried out on diabetes induced male Swiss albino rats by single intramuscular injection of alloxan $(0.15 \mathrm{mg} / \mathrm{kg}$ i.m) and IDDM-rats received $4 \mathrm{~b}, 4 \mathrm{c}$, or $4 \mathrm{~d}(36 \mathrm{mg} / \mathrm{kg}$, p.o). The derivatives were further subjected to insulin secretion by RIN-5F cells confirmed insulinotropic effect. In vitro antioxidant activity was evaluated using enzymatic activities on cell lines In addition, all the synthesized derivatives showed non-toxic effects against a diseased human lung fibroblast (COPD), HCC7231 (TACC CCL-96).

Results: The results revealed that $4 \mathrm{~b}, 4 \mathrm{c}$, and $4 \mathrm{~d}$ showed promising results by substantially lowering the blood glucose levels on $21^{\text {st }}$ day of postadministration. Serum insulin levels substantially rose, suggesting that derivatives exert insulinotropic effects through different pathways. 4c showed oxygen free-radical scavenging activity.

Conclusion: Our study proves that oral administration of 5-naphthalidin-TZD twice a day is a valuable treatment for type II diabetes. It seems to be a good drug moiety endowed significant oxygen free-radical scavenging activity.

Keywords: Diabetes, Free-radical scavenging activity, RIN-5F cells, Diseased human lung fibroblast.

(c) 2021 The Authors. Published by Innovare Academic Sciences Pvt Ltd. This is an open access article under the CC BY license (http://creativecommons.org/ licenses/by/4.0/) DOI: http://dx.doi.org/10.22159/ajpcr.2021v14i7.40792. Journal homepage: https://innovareacademics.in/journals/index.php/ajpcr

\section{INTRODUCTION}

Charaka and Sushruta, the two great men of Indian medicine of yore had described the disease as "Madhumeha," a condition where large quantities of sugar are lost from the body in urine. A historical account reveals that as early as 700-200 B.C. Diabetes Mellitus (DM) was a wellrecognized disorder in India and was even distinguished as two types; one is genetics and other one resulting from dietary indiscretion [1]. It is characterized by means of abnormally rise in blood glucose levels. The diabetic complications are diabetic neuropathy, retinopathy, nephropathy, and cardiovascular diseases [2].

Thiazolidinediones (TZDs; also called as "glitazones") was introduced in late 1990's as an oral addition therapy for type II diabetes mellitus and related diseases. They bind firmly to peroxisome proliferators activated receptor (PPAR $\gamma$ ). This stimulates peripheral adiposities to promote adipogenesis and uptake of free fatty acids (in peripheral but not visceral fat), which leads to reduction in the fat storage [3].

An imbalance between reactive oxygen species (ROS) fabrication and antioxidant scavenging ability induces oxidative stress, which eventually leads to cellular and tissue damage in diabetic patients [4]. These effects can be minimized by neutralizing oxidants or scavenged by increasing antioxidant intake [5].

In this research, we investigated the insulinotropic effect of 5-substituted TZD with standard reference rosiglitazone and on insulinsecreting RIN-5F cells both in vitro and in vivo, which consist of a series of studies such as reduced or inhibited glucose absorption at intestinal level and marginal level, by increasing the entry of glucose into cells. The in vivo studies included the dose- and time-dependent stimulation of $\beta$ pancreatic cells to release insulin in insulin-sensitive tissues and altering associated oxidative stress [6].

The antioxidative events were evaluated using catalase (CAT), superoxide dismutase (SOD), glutathione peroxidase (GPx) on cell lines, that is, diseased human lung fibroblast (COPD), HCC7231 (TACC CCL-96) [7].

\section{METHODS}

Drugs and chemicals

Alloxan procured from Sigma, St. Louis, MO, USA. Ascorbic AcidQualigens, Methanol-Qualigens was of the highest analytical grade available.

\section{Rosiglitazone}

Rosiglitazone is an oral hypoglycemic drug in the thiazolidinedione class of drugs. It acts as PPAR gamma receptors agonist [8].

\section{Synthesis of 2-imino-4-thiazolidinedione}

Synthesis of 2-imino-4-thiazolidinedione was carried out by taking equimolar quantities of 2-chloroethylacetate (104 Moles) with thiourea (96 Moles) and dissolved in ethanol and refluxed over a period of $3 \mathrm{~h}$. The mixture was cooled to room temperature. The $\mathrm{HCl}$ salt which formed was added to water and neutralized with solution of sodium acetate, which precipitated 2-imino-4-thiazolidinedione on cooling. The product was filtered and dried at $60^{\circ} \mathrm{C}$. TLC solvent system ethylacetate: methanol $(1: 2)$.

IR showed absorption at $\left(\mathrm{cm}^{-1}\right)$ : 3074, 3059(-NH, NH-), 1620(-C=O-), and $746(-\mathrm{C}-\mathrm{S}-\mathrm{C}-)$. M.P $=186-188^{\circ} \mathrm{C}$. 

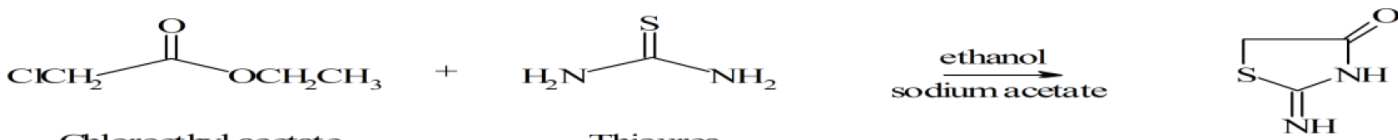

Chloroethyl acetate

Thiourea

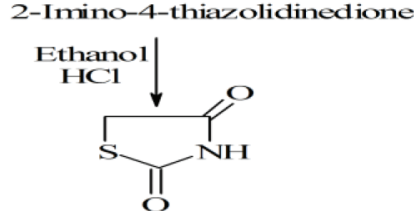

5-[(2-Hydroxy)-naphthylidiene]-
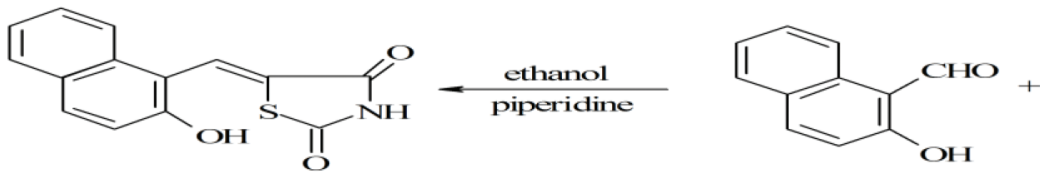

2,4-thiazolidinedione (1)

2-Hydroxy-1 naphthaldehyde

24-Thiazolidinedione<smiles></smiles>

5-\{[(2-Hydroxy)-naphthylidiene]$3-($ N-Carbamate) $\}-2,4$-thiazolidinedione

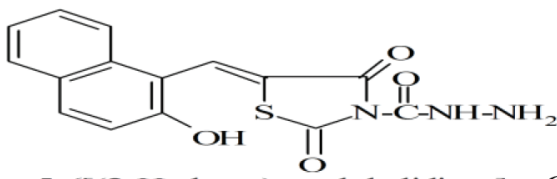

5-\{โ(2-I Hydroxy)-naphthylidiene]- (3) 3-(N-SemiCarbazide) $\}-2,4$-thiazolidinedione<smiles>[R]C=[W]NC(=O)N1C(=O)SC(=Cc2c(O)ccc3ccccc23)C1=O</smiles>

5-\{[(2-Hydroxy)-naphthylidiene $]-$ 3-(N-4 arylmethyl Semicarbazide) $\}$ 2,4-thiazolidinedione (4)<smiles>Cc1ccc([N+](=O)[O-])cc1</smiles>
$4 b=$<smiles>Cc1ccc(C)cc1</smiles>
$4 c=$<smiles>Cc1ccc(O)cc1</smiles>
$4 d=$

\section{Synthesis of 2, 4-thiazolidinedione}

The 2-Imino-4-thiazolidinedione was hydrolyzed with $2 \mathrm{~N} \mathrm{HCl}$ in ethanol by refluxing for $15 \mathrm{~h}$. The reaction mixture cooled was neutralized with saturated solution of $\left.\mathrm{NaHCO}_{3}, 10 \%\right)$. The crude product 2-4-thiazolidinedione was separated as solid. This was recrystallized from ethanol: water (40:60) mixture. TLC solvent system ethylacetate: methanol (1:2)

Synthesis of 5-[(2-Hydroxy)-naphthylidene]-2,4-thiazolidinedione Equimolar amounts of variously substituted aldehydes and 2,4-thiazolidinedione were refluxed in absolute ethanol (till the sample dissolves) for $4 \mathrm{~h}$ in the presence of piperidine. The mixture was cooled and poured on to crushed ice with stirring. The product obtained is washed with toluene to give 5-[(2-Hydroxy)- naphthylidene] - 2,4-thiazolidinedione. TLC solvent system used ethylacetate: methanol (1:2).

Synthesis of 5-[(2-hydroxy)-naphthylidene]-3- (N-carbamate)-2,4thiazolidinedione

5-[(2-Hydroxy)-naphthylidene]-2,4-Thiazolidinedione $\quad(0.1$ mole) and triethylamine $(0.15$ mole) in DMF $(150 \mathrm{ml})$ were added methyl chloroformate $(0.15$ mole $)$ drop wise at $0-5^{\circ} \mathrm{C}$. Then, the reaction mixture was refluxed for $15 \mathrm{~h}$ in an oil bath. The reaction was continuously monitored by TLC using toluene: ethylacetate (1:1). Later the reaction is poured into dil. $\mathrm{HCl}(160 \mathrm{ml}, 50 \% \mathrm{v} / \mathrm{v})$ with constant stirring. The crude product obtained was filtered, dried, and purified by crystallization using absolute alcohol.
Synthesis of 5-[(2-hydroxy)-naphthylidene]-3-(Nsemicarbazide)-2,4 thiazolidinedione

The mixture of 5-[(2-hydroxy)-naphthylidene]-3- (N- carbamate)-2, 4-thiazolidinedione $(0.1 \mathrm{~mole})$ and hydrazine hydrate $(0.43 \mathrm{~mole})$ in alcohol (till the sample dissolves) was heated in an oil bath for $18 \mathrm{~h}$. The reaction progress was monitored by TLC using toluene: ethylacetate (1:1). Cooled reaction gives yellow crystals. Re-crystallization by absolute alcohol is done.

Synthesis of 5-[(2-hydroxy)-naphthylidene]-3-(N-41 arylmethyl semicarbazide)-2, 4-thiazolidinedione

A mixture of 5-[(2-Hydroxy)-naphthylidene]-3-(N-semicarbazide)-2,4thiazolidine dione $(0.01$ mole), substituted aldehydes ( 0.012 mole), and hydrochloric acid $(0.18 \mathrm{ml})$ was refluxed for $4 \mathrm{~h}$. Progress of the reaction was checked by TLC using toluene: ethylacetate (1:1) as eluent. The solid obtained was filtered, dried, and crystallized from absolute alcohol to give 5-[(2-Hydroxy)-naphthylidene]-3-(N-4 ${ }^{1}$ arylmethyl semi-carbazide)-2,4-thiazolidinedione.

General procedure for synthesis of substituted 5-[(2-hydroxy)naphthylidene]-3-( $\mathrm{N}-4^{1}$ arylmethyl semicarbazide)-2, 4-thiazolidinedione (4a-g)

To a continuously stirred mixture of compound $4(0.35 \mathrm{~g}, 0.00110 \mathrm{~mol})$ and appropriate arylidine compounds $(0.3 \mathrm{~g}, 0.00110 \mathrm{~mol})$ in ethanol $(8 \mathrm{~mL})$, few drops of piperidine were added. The reaction mass was refluxed for 6-8 h. The progress of the reaction was continuously monitored by TLC. After cooling, the separated solid or residue was filtered, washed with hot ethanol. All the compounds were further 
purified by re-crystallized in ethanol to get the desired title compounds (4a-g).

\section{In vivo and in vitro screening for anti-diabetic activites}

Animals [9-10]

Male albino rats weighing 150-200 g were used for this study. Rats were caged under controlled temperature of $20-24^{\circ} \mathrm{C}$ and maintained on $12 \mathrm{~h}$ light/dark cycle. They were fed with standard laboratory pellets and water ad libitum. For induction of diabetes, rats were kept on fasting before alloxan injection (Sigma-Aldrich) (150 mg/kg body weight in $0.9 \% \mathrm{NaCl}, \mathrm{pH} 4.5$ ) by intraperitoneal route.

The animals were fed with commercially available rat pelleted diet (Sai Durga feeds and foods, Bangalore). Water was allowed ad libitum under strict hygienic conditions. The study protocols were duly approved by the Institutional Animal Ethics Committee (IAEC) of College of Pharmaceutical Sciences, Dayananda Sagar University (DSU/PhD/IAEC/09/2017-18), Bengaluru and studies were performed in accordance with the CPCSEA guidelines.

\section{Experimental design [11-13]}

In the present investigation, a total of 36 rats (30 diabetic surviving rats and six normal rats) were divided into six groups of six rats each. Control rats were treated with carboxymethyl cellulose (CMC) alone. The rats with a blood glucose level above $150 \mathrm{mg} / \mathrm{dl}$ were considered to be diabetic and used in the experiment for 15 day treatment.

- Group I: Normal control - Received 0.25\% CMC p.o and sterile water for injection i.m.

- Group II: Alloxan control - Received 0.25\% CMC p.o and alloxan 0.15 mg/kg i.m.

- Group III: Rosiglitazone treated - Received rosiglitazone $500 \mu \mathrm{g} / \mathrm{kg}$ body weight i.p.

- Group IV: Received 4b, $36 \mathrm{mg} / \mathrm{kg}$ in $0.25 \%$ CMC p.o and alloxan 0.15 mg/kg i.m.

- Group V: Received 4c, $36 \mathrm{mg} / \mathrm{kg}$ in $0.25 \%$ CMC p.o and alloxan $0.15 \mathrm{mg} / \mathrm{kg}$ i.m.

- Group VI: Received 4d, $36 \mathrm{mg} / \mathrm{kg}$ in $0.25 \%$ CMC p.o and alloxan 0.15 mg/kg i.m.

Treatment was continued for 15 days. On day 15, after overnight fasting, blood samples were collected by withdrawing a drop of blood from tail vein by tail tipping method. The blood was dropped on the reagent strip and inserted into the digital blood glucometer and the readings were noted.

\section{In vitro studies using RIN-5F cells [14-17]}

Rin- $5 \mathrm{~F}$ cells, that is, rat pancreatic beta cell line were grown in polyL-lysine-coated $75 \mathrm{~cm} 2$ flasks $(\sim 2.0-2.5 \times 106$ cells $/ \mathrm{mL})$ in RPMI1640 and the medium is supplemented with $1 \%$ nonessential amino acids, $2 \mathrm{mM}$ glutamine, and 10\% heat-inactivated fetal bovine serum in a humidified incubator in the existence of 5\%-95\% carbon dioxide air at temperature of $37^{\circ} \mathrm{C}$. Cells were brought in contact with different concentrations of alloxan (0-10 mM) dissolved in citrate buffer, $\mathrm{pH} 4.4$, and diluted in RPMI1640 to proper concentrations just before its use at different time intervals $(24 \mathrm{~h}-48 \mathrm{~h})$. Control cells were treated with CMC alone. Dose-dependent and time-dependent alloxan treatment were based on MTT tests. After the preferred time of treatment, harvested cells were collected and washed with PBS (pH 7.4), and homogenized in H-medium buffer (70 mM sucrose, $220 \mathrm{mM}$ mannitol, $2.5 \mathrm{mM}$ HEPES, $2 \mathrm{mM}$ EDTA, and $0.1 \mathrm{mM}$ phenylmethylsulfonyl fluoride, $\mathrm{pH} 7.4$ ) at $4^{\circ} \mathrm{C}$. The mitochondrial and post-mitochondrial fractions were isolated by differential centrifugation. Cross contaminations were checked to know the purity of the isolated fractions. The protein concentration was determined by incubating the cells for $20 \mathrm{~min}$ with $1 \mathrm{~mL} \mathrm{KRB}$ and 1.1 $\mathrm{mM}$ glucose in the presence of $4 \mathrm{~b}, 4 \mathrm{c}$, and $4 \mathrm{~d}$. After the completion of incubation, aliquots were removed from each well and stored at $-20^{\circ} \mathrm{C}$ for insulin assay. Insulin release was measured using insulin ELISA kit (Crystal Chem, USA).

\section{In vitro screening for antioxidant activity $[18,19]$}

\section{Cell culture}

Human lung fibroblast (COPD), HCC7231 (TACC CCL-96) cells were preserved at $37^{\circ} \mathrm{C}$ in an incubator with a humidified atmosphere of $5 \% \mathrm{CO}_{2} / 95 \% \mathrm{O}_{2}$. Cells were cultured in Dulbecco's modified Eagle's medium (DMEM, Sigma-Aldrich, India) containing 5\% fetal bovine serum (FBS, Sigma-Aldrich, India), $100 \mathrm{mg} / \mathrm{ml}$ of streptomycin, 100 unit/ml of phenoxy methyl penicillin by Sigma-Aldrich, India, and $2 \mathrm{mM}$ L-glutamine (Sigma-Aldrich, India)

\section{Cell viability [17]}

Mitochondrial dehydrogenase (MTT) based cell viability test a colorimetric method used to evaluate the number of healthy cells in a sample. The Human lung fibroblast (COPD), HCC7231 (TACC CCL-96) was seeded in a 96 well plate at a concentration of $1.2 \times 105$ cells $/ \mathrm{ml}$ in a culture medium and $16 \mathrm{~h}$ after plating, cells were treated with $\mathbf{4 b}$, 4c, and 4d derivatives were added separately at the concentration of $100 \mathrm{mg} / \mathrm{ml}$ and $1 \mathrm{~h}$ later $1 \mathrm{mM} \mathrm{H}_{2} \mathrm{O}_{2}$ was added to the culture and incubated for $24 \mathrm{~h}$ at $37^{\circ} \mathrm{C}$, with $5 \% \mathrm{CO}_{2}$ in a humidified atmosphere and DMSO without sample is considered as control. The water insoluble formazan so formed can be solubilized using DMSO and the viable cells were quantitated at $570 \mathrm{~nm}$ on an ELISA reader.

$$
\% \text { Cytotoxicity }=\left(A_{\text {control }}-A_{\text {sample }}\right) /\left(A_{\text {control }}\right) \times 100
$$

Where, $\mathrm{A}$ is the absorbance of sample and A is the absorbance of control.

\section{Serum preparation [20]}

The blood used for serum preparation were collected from all the animals through direct puncturing the retro orbital plexus with $21 \mathrm{G}$ needle attached to $5 \mathrm{~mL}$ syringe, following mild ketamine anesthesia of the rats. The serum was prepared using standard method as described by Kohen. Blood was allowed to clot for $30 \mathrm{~min}$ and then centrifuged at $2500 \mathrm{rpm}$ for $15 \mathrm{~min}$ and serum was collected.

\section{Superoxide dismutase (SOD) activity [21]}

Superoxide dismutase activity was assayed using $50 \mathrm{ml}$ of xanthine oxidase $(0.1 \mathrm{mg} / \mathrm{ml})$ was used to generate a superoxide, which has a strong absorbance at $560 \mathrm{~nm}$ and nitroblue tetrazolium (NBT) was used as an indicator of superoxide production. SOD activity was then measured by the degree of inhibition of the reaction unit of enzyme providing 50\% inhibition of NBT reduction. Results are expressed as $\mathrm{U} / \mathrm{mL}$.

\section{Catalase (CAT) activity [22]}

The basic principle involved here is the disappearance of $\mathrm{H}_{2} \mathrm{O}_{2}$ in the presence of the enzyme source at $26^{\circ} \mathrm{C}$. The reaction mixture contained $1.2 \mathrm{mM}$ of $3 \%(\mathrm{v} / \mathrm{v}) \mathrm{H}_{2} \mathrm{O}_{2}$ and $0.2 \mathrm{ml}$ of serum $(10 \mu \mathrm{L})$ in $0.05 \mathrm{M}$ phosphate buffer ( $\mathrm{pH} \mathrm{7.0)}$ at a final volume of $1.0 \mathrm{ml}$. Samples were allowed to stand for $25 \mathrm{~min}$ and the decomposition rate of hydrogen peroxide was measured at $240 \mathrm{~nm}$ for $5 \mathrm{~min}$ on a spectrophotometer. The change in absorbance is proportional to the breakdown of $\mathrm{H}_{2} \mathrm{O}_{2}$. A molar extinction coefficient of $0.041 \mathrm{mM}^{-1} \mathrm{~cm}^{-1}$ was used to calculate the activity.

\section{Glutathione peroxidase (GPX) activity [23]}

The GPx activity in the serum was determined by the method used by Sarma et al. and one unit of GPx activity was defined as the amount of enzyme required to oxidize $1 \mu \mathrm{mol}$ of $\mathrm{NADPH}$ per minute at $30^{\circ} \mathrm{C}$ at $\mathrm{pH} 7.0$ and it is measured at $340 \mathrm{~nm}$.

\section{RESULTS}

The body weights of normal and diabetic rats were significantly $(p<0.001)$ decreased in the alloxan induced diabetic group with comparison to control. The data showed a progress in the body weight 
after 21 days of supplementation, the animals started to gain their normal weight back as shown in Fig. 1.

Administration of 5-naphthalidin-thiazolidinedione derivatives 4b, 4c, and $4 \mathrm{~d}$ in alloxan induced diabetic rats produced a major reduction in serum glucose levels when compared with control are shown in Fig. 2.

5-naphthalidin-thiazolidinedione derivatives $4 \mathrm{~b}$ and $4 \mathrm{~d}$ produced a dose-dependent stimulatory effect on insulin secretion by RIN-5F cells proved to be having promising insulinotropic property as shown in Fig. 3.

The biological antioxidant activity and cell viability was carried on diseased human lung fibroblast (COPD), HCC7231 (TACC CCL-96) cell lines. This resulted showed a remarkable protection of cell lines from oxidative stress induced by free radicals as shown in Fig. 4.

The serum level of SOD, CAT, and GPx of experimental diabetic rats was carried out and the results are shown in Tables 1-4 and they protect organisms from increasing ROS and act as the main defense system.

\section{DISCUSSION}

Based on the literature survey Alloxan-induced diabetes mellitus has been described as an exploitable experimental model to study the activity of oral anti-diabetic agents. Diabetes is the major grooming health problem throughout the world, in the present paper, we

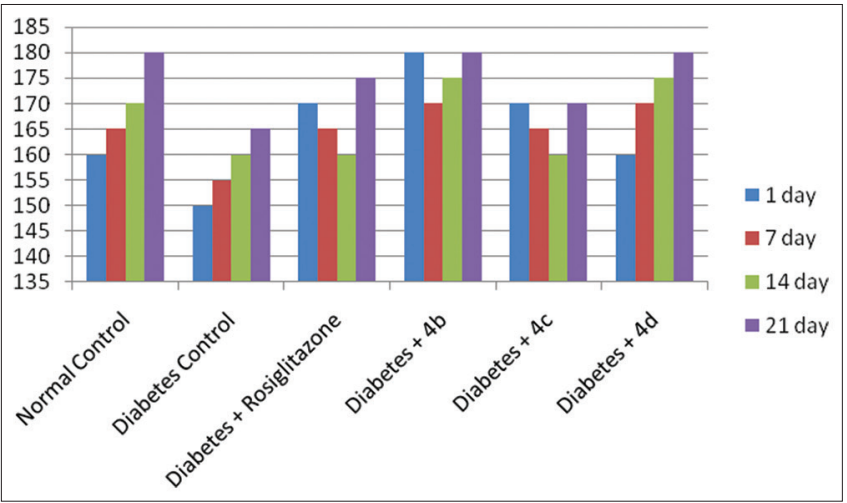

Fig. 1: Changes in rats' body weight (g). Each bar represents the mean $\pm S D$ of rats. $4 b, 4 c$, and $4 d$ and the values were expressed as mean \pm SD

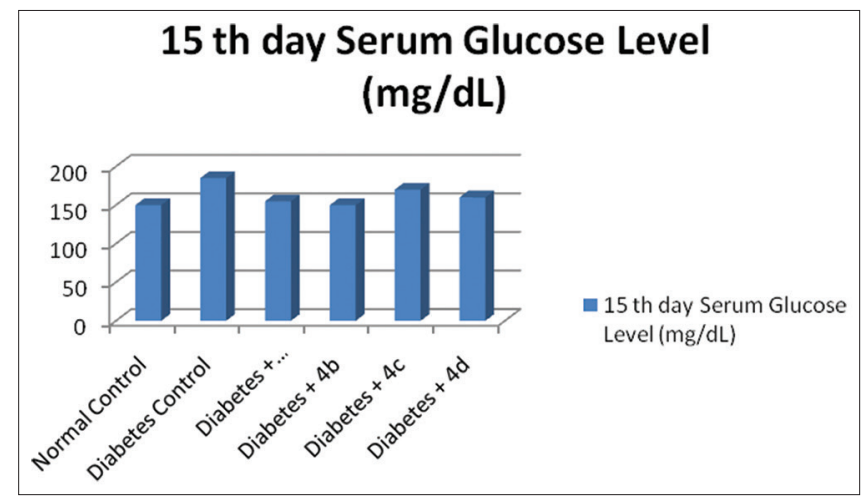

Fig. 2: Effect of derivatives on blood glucose levels $(\mathrm{mg} / \mathrm{dl})$ in alloxan-induced insulin resistant model in rats. Fasting blood glucose level in the $4 \mathrm{~b}, 4 \mathrm{c}$, and $4 \mathrm{~d}$ treated rats, decrease in blood glucose level was prominent from day 1 onward; the decrease in blood glucose level was highly pronounced after Day 15 . The hypoglycemic effect of $4 \mathrm{~b}, 4 \mathrm{c}$, and $4 \mathrm{~d}$ at $36 \mathrm{mg} / \mathrm{kg}$ dose was more prominent than rosiglitazone (the reference standard) have decided to synthesize some new 5-substituted thiazolidinone derivatives as shown in scheme and evaluate them for their possible insulinotropic effect. The structure of new compounds synthesized during present investigation has been authentically established by their UV, FTIR, $\mathrm{H}^{1} \mathrm{NMR}$, and $\mathrm{C}^{13} \mathrm{NMR}$.

As shown in the scheme cyclisation of 2-chloro ethyl acetate with thiourea in ethanol to give 2-Imino-thiazolidinedione followed by hydrolysis with $\mathrm{HCl}$ to afford 2,4-Thiazolidinedione. On condensation with 2-hydroxynaphthaldehyde in the presence of piperidine to form 5-[(2-Hydroxy)-naphthylidene]-2,4-thiazolidinedione which on treatment with methyl chloroformate yielded 5-[(2-Hydroxy)naphthylidene]-3-(N-Carbamate)-2,4-thiazolidinedione. This was followed by condensation with hydrazinehydrate to give 5 - [(2-Hydroxy) - na phthylid en e]-3-(N-semicarbazide) - 2,4 thiazolidinedione. This semicarbazide was transformed into semicarbazones by condensation with substituted aromatic aldehydes to get 5-[(2-Hydroxy)-naphthylidene]-3-( $\mathrm{N}-4^{1}$ arylmethyl semicarbazide)-2,4-thiazolidinedione, using this as a parent compound derivatives 4a-e was synthesized [24].

The in vivo and in vitro oral hypoglycemic activity of 5- naphthylidene TZD derivatives was screened for the prominent action on insulin secretion. This could be due to the insulin secretagogue effect of antihyperglycemic constituents, C5 substituted groups in TZD, which are generally more active than thiazolidine analogs. The results

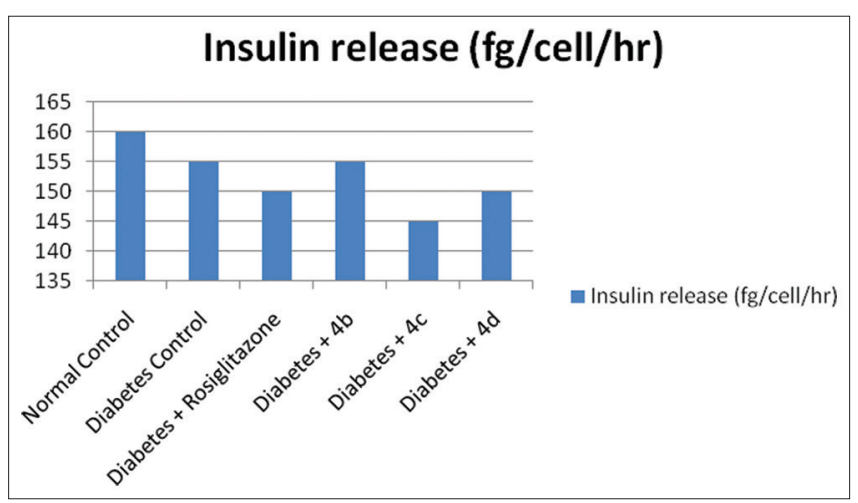

Fig. 3: Effects of derivatives on insulin secretion by RIN-5F cells [26]. Rosiglitazone (0.2-20 $\mathrm{mM})$ produced a dose-dependent and time dependent stimulatory effect on insulin secretion by RIN-5F cells. However, concentrations of rosiglitazone less than $20 \mathrm{mM}$ did not significantly enhance the insulin-releasing effect. As seen in treatment of RIN-5F cells with different concentrations of $4 b, 4 c$, and $4 d(10 \mathrm{mg} / \mathrm{mL})$ significantly increase the levels of insulin as compared with the control

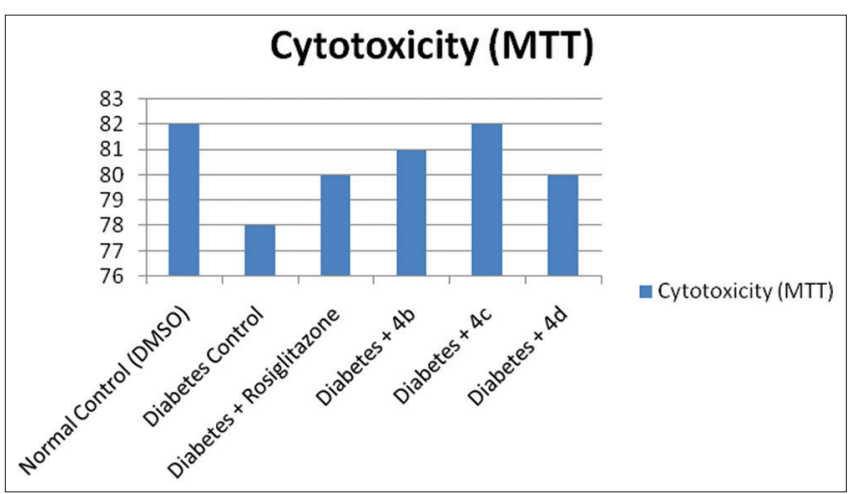

Fig. 4: Cytotoxic effect of 4b, 4c, and 4d was readably determined against diseased human lung fibroblast (COPD), HCC7231 (TACC CCL-96) by MTT assay. Values were expressed as mean \pm SD. 3-(4, 5-dimethylthiazol-2-yl)-2, 5-diphenyltetrazolium bromide (MTT) 
Table 1: Physical properties of synthesized compounds

\begin{tabular}{lllll}
\hline S. No. & C.C.* & State & \% yield & MP \\
\hline 1 & $4 \mathrm{a}$ & Yellow orange solid & 58 & $210-215^{\circ} \mathrm{C}$ \\
2 & $4 \mathrm{~b}$ & Pale Yellow solid & 48 & $235-240^{\circ} \mathrm{C}$ \\
3 & $4 \mathrm{c}$ & Yellow solid & 50 & $210-215^{\circ} \mathrm{C}$ \\
4 & $4 \mathrm{~d}$ & Yellow solid & 55 & $220-225^{\circ} \mathrm{C}$ \\
5 & $4 \mathrm{e}$ & Yellow solid & 48 & $225-230^{\circ} \mathrm{C}$ \\
6 & $4 \mathrm{f}$ & Yellow solid & 52 & $205-215^{\circ} \mathrm{C}$ \\
7 & $4 \mathrm{~g}$ & Yellow solid & 60 & $215-230^{\circ} \mathrm{C}$ \\
\hline
\end{tabular}

Table 2: Elemental and spectral analysis data of synthesized compounds

\begin{tabular}{|c|c|c|}
\hline $\begin{array}{l}\text { Comp. } \\
\text { Code }\end{array}$ & $\begin{array}{l}\text { Elemental analysis } \\
\text { (calculated) }\end{array}$ & IR. values $\left(\mathrm{cm}^{-1}\right)$ \\
\hline $4 a$ & $\begin{array}{l}C=63.31, H=6.71, \\
N=7.77, O=13.32, \\
S=8.90\end{array}$ & $\begin{array}{l}3110.17 \text { (N-H Str.), } 3050.78 \\
\text { (Ar-H Str.), } 2962.89 \text { (C-H Str. of } \mathrm{CH}_{3} \text { ), } \\
1693.70 \text { (C=0 Str.), } 1600.52 \text { (C=C Str.), } \\
1512.47 \text { (C=N Str.) }\end{array}$ \\
\hline $4 b$ & $\begin{array}{l}C=59.65, H=6.12, \\
N=7.73, O=17.66, \\
S=8.85\end{array}$ & $\begin{array}{l}3009.90 \text { (N-H Str.), } 2932.45 \\
\text { (Ar-H Str.), } 2835.61 \text { (C-H Str. of } \mathrm{CH}_{3} \text { ), } \\
1720.49 \text { (C=O Str.), } 1635 \text { (C=C Str.), } \\
1600.06 \text { (C=N Str.) }\end{array}$ \\
\hline $4 c$ & $\begin{array}{l}C=61.31, H=5.71, \\
N=6.77, O=11.32, \\
S=7.90\end{array}$ & $\begin{array}{l}3120.74 \text { (N-H Str.), } 3015.85 \text { (Ar-H } \\
\text { Str.), } 2964 \text { (C-H Str. of } \mathrm{CH}_{3} \text { ), } 1700 \\
\text { (C=0 Str.), } 1591.59 \text { (C=C Str.), } 1515.23 \\
\text { (C=N Str.) }\end{array}$ \\
\hline $4 d$ & $\begin{array}{l}C=61.31, H=6.31, \\
N=7.17, O=13.12, \\
S=7.90\end{array}$ & $\begin{array}{l}3000.21 \text { (N-H Str.), } 2950.09 \text { (Ar- } \\
\text { H Str.), } 2835.81 \text { (C-H Str. of } \mathrm{CH}_{3} \text { ), } \\
1715.41 \text { (C=O Str.), } 1628.05 \text { (C=C Str.), } \\
1510.55 \text { (C=N Str.) }\end{array}$ \\
\hline $4 e$ & $\begin{array}{l}C=59.31, H=7.71, \\
N=6.77, O=11.32, \\
S=7.90\end{array}$ & $\begin{array}{l}3075.62 \text { (N-H Str.), } 2910.80 \text { (Ar- } \\
\text { H Str.), } 2850.79 \text { (C-H Str. of } \mathrm{CH}_{3} \text { ), } \\
1718.58 \text { (C=0 Str.), } 1625.09 \text { (C=C Str.), } \\
1600.95 \text { (C=N Str.) }\end{array}$ \\
\hline $4 \mathrm{f}$ & $\begin{array}{l}C=38.91, H=3.46, \\
N=21.96, O=30.32, \\
S=25.38\end{array}$ & $\begin{array}{l}3200.99 \text { (N-H Str.), } 3100.46 \text { (Ar-H } \\
\text { Str.), } 2850.65 \text { (CH Str. of } \mathrm{CH}_{3} \text { ), } 1650.41 \\
\text { (C=O Str.), } 1600.30 \text { (C=C Str.), } 1591.71 \\
\text { (C=N Str.) }\end{array}$ \\
\hline $4 \mathrm{~g}$ & $\begin{array}{l}C=60.31 ; H=1.95 ; \\
N=20.05 ; O=24.68 ; \\
S, 11.38\end{array}$ & $\begin{array}{l}3317.23 \text { (N-H Str.), } 3100.86 \text { (Ar- } \\
\text { H Str.), } 2900.41 \text { (C-H Str. of } \mathrm{CH}_{3} \text { ), } \\
1700.20 \text { (C=O Str.), } 1630.90 \text { (C=C Str.), } \\
1530.99 \text { (C=N Str.) }\end{array}$ \\
\hline
\end{tabular}

of this study also demonstrated that $4 \mathrm{~b}, 4 \mathrm{c}$, and $4 \mathrm{~d}$ for 21 days had regenerative potential with increased insulin secretion from $\beta$-cells of islets of Langerhans of pancreas in alloxan-induced diabetic rats as shown in the Fig. 2. The reduction in serum glucose activity of derivatives was compared with standard reference rosiglitazone. From the results of the present study, it may be suggested that the mechanism of action of 5-naphthylidene TZD may be similar to rosiglitazone action.

Pancreatic $\beta$-cells play a key role in the production of insulin; therefore, we used RIN-5F cells (a rat islet cell line) to examine the levels of insulin. The direct exposure of 5 - naphthylidene TZD derivatives to $\beta$-cells of Langerhans causes stimulation of cells to release insulin as shown in Fig. 3.

The MTT assay as shown in Fig. 4 revealed that exposure to $4 \mathrm{~b}, 4 \mathrm{c}$ and $4 \mathrm{~d}$ significantly reduced cell viability of diseased human lung fibroblast (COPD), HCC7231 (TACC CCL-96) cell lines, compared to the normal cell line group. Enzymatic antioxidant activity of TZD derivatives $4 \mathrm{~b}, 4 \mathrm{c}$, and $4 \mathrm{~d}$ was screened using endogenous enzymes (GPx, CAT, and SOD) as shown in Tab-4.4c showed promising activity proving that 5-naphthylidene TZD derivatives emerged out as good anti-diabetic and promising antioxidant drug [25]. Derivatives induced
Table 3: $\mathrm{H}^{1} \mathrm{NMR}$ and $\mathrm{C}^{13} \mathrm{NMR}$ data of synthesized compounds [7]

\begin{tabular}{|c|c|c|}
\hline $\begin{array}{l}\text { Comp. } \\
\text { Code }\end{array}$ & $\begin{array}{l}\text { H}^{1} \mathrm{NMR}(400 \mathrm{MHz} \\
\left.\text { DMSO- } d_{6}, \delta, \mathrm{ppm}\right)\end{array}$ & $\begin{array}{l}\mathrm{C}^{13} \mathrm{NMR} \text { (100 MHz, DMSO, } \\
\delta \text { ppm) }\end{array}$ \\
\hline $4 a$ & $\begin{array}{l}9.51(\mathrm{~s}, 1 \mathrm{H}, \mathrm{NH}), 6.97- \\
6.96(\mathrm{~d}, 1 \mathrm{H}, J=5.00 \mathrm{~Hz}) \\
6.86(\mathrm{~s}, 1 \mathrm{H}, \mathrm{C}=\mathrm{C}-\mathrm{H}) \\
8.62-7.61(\mathrm{~d}, 1 \mathrm{H}, J=3.44 \\
\mathrm{Hz}), 6.30(\mathrm{~s}, 1 \mathrm{H}, \mathrm{Ar}-\mathrm{H}) \\
6.22-7.00(\mathrm{~m}, 2 \mathrm{H}), 6.50- \\
6.75(\mathrm{~m}, 2 \mathrm{H}), 2.84 \\
\left(\mathrm{~s}, 3 \mathrm{H},-\mathrm{OCH}_{3}\right), 2.78 \\
\left(\mathrm{~s}, 3 \mathrm{H},-\mathrm{OCH}_{3}\right)\end{array}$ & $\begin{array}{l}166.91(\mathrm{C}=\mathrm{O} \text {, thiazolidin-4-one), } \\
162.70(\mathrm{C}=\mathrm{N}, 2 \text {-ylidene carbon), } \\
160.30(\mathrm{C}=\mathrm{N} \text { of thiazolidinone), } \\
150.75,14999,135.82,132.59, \\
133.23,130.82,129.87,127.24, \\
121.18(\mathrm{C}-\mathrm{H}, \text { benzylidene } \\
\text { carbon), } 121.98(\mathrm{C}-5 \text { of } \\
\text { thiazolidinone), } 56.54\left(-\mathrm{OCH}_{3}\right)\end{array}$ \\
\hline $4 \mathrm{~b}$ & $\begin{array}{l}11.61(\mathrm{~s}, 1 \mathrm{H}, \mathrm{NH}), 7.72- \\
7.71(\mathrm{~d}, 2 \mathrm{H}, J=5.04 \mathrm{~Hz}) \\
6.57-7.56(\mathrm{~d}, 2 \mathrm{H}, J=5.10 \\
\mathrm{Hz}), 6.53(\mathrm{~s}, 1 \mathrm{H}, \mathrm{C}=\mathrm{C}-\mathrm{H}) \\
6.27(\mathrm{~s}, 1 \mathrm{H}, \mathrm{Ar}-\mathrm{H}), 6.18- \\
7.17(\mathrm{~d}, 1 \mathrm{H}, J=8.28 \mathrm{~Hz}) \\
5.99-6.25(\mathrm{~d}, 1 \mathrm{H}, J=8.22 \\
\mathrm{Hz}), 2.84\left(\mathrm{~s}, 3 \mathrm{H},-\mathrm{OCH}_{3}\right)\end{array}$ & $\begin{array}{l}166.20(\mathrm{C}=\mathrm{O} \text {, thiazolidin-4-one }), \\
165.59(\mathrm{C}=\mathrm{N}, 2 \text {-ylidene carbon }), \\
157.53(\mathrm{C}=\mathrm{N} \text { of thiazolidinone), } \\
151.97,150.71,140.31 \\
135.19,130.51,130.18(\mathrm{C}-5 \text { of } \\
\text { thiazolidinone }), 125.18(\mathrm{C}-\mathrm{H}, \\
\text { benzylidene carbon }), 124.70, \\
62.31,58.18\left(-\mathrm{OCH}_{3}\right)\end{array}$ \\
\hline $4 c$ & $\begin{array}{l}11.50(\mathrm{~s}, 1 \mathrm{H}, \mathrm{NH}), 7.25 \\
(\mathrm{~s}, 1 \mathrm{H}, \mathrm{Ar}-\mathrm{H}), 7.42 \\
(\mathrm{~s}, 1 \mathrm{H}, \mathrm{C}=\mathrm{C}-\mathrm{H}), 7.26-7.34 \\
(\mathrm{~d}, 2 \mathrm{H}, \mathrm{J}=8.04 \mathrm{~Hz}), 7.30 \\
(\mathrm{~s}, 1 \mathrm{H}, \mathrm{Ar}-\mathrm{H}), 7.20-7.15 \\
(\mathrm{~m}, 2 \mathrm{H}), 6.78-6.82 \\
(\mathrm{~m}, 2 \mathrm{H}), 2.84(\mathrm{~s}, 3 \mathrm{H}, \\
\left.-\mathrm{OCH}_{3}\right), 2.31\left(\mathrm{~s}, 3 \mathrm{H},-\mathrm{CH}_{3}\right)\end{array}$ & $\begin{array}{l}168.22(\mathrm{C}=0 \text {, thiazolidin-4-one), } \\
164.59(\mathrm{C}=\mathrm{N}, 2 \text {-ylidene carbon), } \\
157.80(\mathrm{C}=\mathrm{N} \text { of thiazolidinone), } \\
150.51,140.24,137.26,135.41, \\
131.88,130.84(\mathrm{C}-\mathrm{H}, \text { benzylidene } \\
\text { carbon }), 130.80,128.75,127.29, \\
125.06(\mathrm{C}-5 \text { of thiazolidinone), } \\
56.47\left(-\mathrm{OCH}_{3}\right), 20.04\left(-\mathrm{CH}_{3}\right)\end{array}$ \\
\hline $4 \mathrm{~d}$ & $\begin{array}{l}11.66(\mathrm{~s}, 1 \mathrm{H}, \mathrm{NH}), 8.65 \\
(\mathrm{~s}, 1 \mathrm{H}, \mathrm{C}=\mathrm{C}-\mathrm{H}), 7.60- \\
7.59(\mathrm{~d}, 1 \mathrm{H}, J=3.76 \mathrm{~Hz}) \\
7.02-8.01(\mathrm{~d}, 1 \mathrm{H}, J=7.00 \\
\mathrm{Hz}), 6.62(\mathrm{~s}, 1 \mathrm{H}, \mathrm{C}=\mathrm{C}-\mathrm{H}) \\
6.58-6.55(\mathrm{dd}, 1 \mathrm{H}, \\
J=7.89,4.24 \mathrm{~Hz}), 628 \\
(\mathrm{~s}, 1 \mathrm{H}, \mathrm{Ar}-\mathrm{H}), 4.83 \\
\left(\mathrm{~s}, 3 \mathrm{H},-\mathrm{OCH}_{3}\right)\end{array}$ & $\begin{array}{l}168.85(\mathrm{C}=\mathrm{O}, \text { thiazolidin-4-one), } \\
164.93(\mathrm{C}=\mathrm{N}, 2 \text {-ylidene carbon), } \\
158.39(\mathrm{C}=\mathrm{N} \text { of thiazolidinone), } \\
152.05,150.76,149.96,138.69, \\
136.79,130.81,138.82,128.16, \\
126.70(\mathrm{C}-5 \text { of thiazolidinone), } \\
126.30(\mathrm{C}-\mathrm{H}, \text { benzylidene } \\
\text { carbon), } 125.09,56.47\left(-\mathrm{OCH}_{3}\right)\end{array}$ \\
\hline $4 \mathrm{e}$ & $\begin{array}{l}11.54(\mathrm{~s}, 1 \mathrm{H}, \mathrm{NH}), 6.68 \\
(\mathrm{~s}, 1 \mathrm{H}, \mathrm{C}=\mathrm{C}-\mathrm{H}), 6.56-7.48 \\
(\mathrm{~m}, 5 \mathrm{H}, \mathrm{Ar}-\mathrm{H}), 7.14(\mathrm{~s} \\
1 \mathrm{H}, \mathrm{C}=\mathrm{C}-\mathrm{H}), 6.02-7.00 \\
(\mathrm{~d}, 1 \mathrm{H}, \mathrm{J}=8.76 \mathrm{~Hz}), 2.80 \\
\left(\mathrm{~s}, 3 \mathrm{H},-\mathrm{OCH}_{3}\right)\end{array}$ & $\begin{array}{l}168.06(\mathrm{C}=\mathrm{O} \text {, thiazolidin-4-one), } \\
161.99(\mathrm{C}=\mathrm{N}, 2 \text {-ylidene carbon), } \\
156.76(\mathrm{C}=\mathrm{N} \text { of thiazolidinone), } \\
151.12,149.95,150.97,151.87, \\
134.77,130.01,130.50,129.23, \\
129.71,128.01(\mathrm{C}-\mathrm{H}, \text { benzylidene } \\
\text { carbon), } 124.14(\mathrm{C}-5 \text { of } \\
\text { thiazolidinone), } 118.39,56.43 \\
\left(-\mathrm{OCH}_{3}\right)\end{array}$ \\
\hline $4 \mathrm{f}$ & $\begin{array}{l}11.43(\mathrm{~s}, 1 \mathrm{H}, \mathrm{NH}), 8.55 \\
(\mathrm{~s}, 1 \mathrm{H}, \mathrm{C}=\mathrm{C}-\mathrm{H}), 6.44(\mathrm{~s}, \\
1 \mathrm{H}, \mathrm{C}=\mathrm{C}-\mathrm{H}), 6.28(\mathrm{~s}, 1 \mathrm{H}, \\
\mathrm{Ar}-\mathrm{H}), 6.25(\mathrm{~s}, 1 \mathrm{H}, \mathrm{Ar}-\mathrm{H}) \\
5.97-5.95(\mathrm{~d}, 1 \mathrm{H}, J=8.40 \\
\mathrm{Hz}), 4.13\left(\mathrm{~s}, 3 \mathrm{H},-\mathrm{OCH}_{3}\right) \\
4.00\left(\mathrm{~s}, 3 \mathrm{H},-\mathrm{OCH}_{3}\right), 3.82 \\
\left(\mathrm{~s}, 3 \mathrm{H},-\mathrm{OCH}_{3}\right)\end{array}$ & $\begin{array}{l}168.25(\mathrm{C}=\mathrm{O} \text {, thiazolidin-4-one }), \\
165.88(\mathrm{C}=\mathrm{N}, 2 \text {-ylidene carbon }), \\
165.16(\mathrm{C}=\mathrm{N} \text { of thiazolidinone), } \\
149.39,150.19,158.95,125.31, \\
127.24,129.88(\mathrm{C}-\mathrm{H}, \text { benzylidene } \\
\text { carbon }), 120.36,122.55,124.46, \\
118.14,116.03,58.63\left(-\mathrm{OCH}_{3}\right), \\
54.51\left(-\mathrm{OCH}_{3}\right), 56.47\left(-\mathrm{OCH}_{3}\right)\end{array}$ \\
\hline $4 \mathrm{~g}$ & $\begin{array}{l}11.88(\mathrm{~s}, 1 \mathrm{H}, \mathrm{NH}), 6.70 \\
(\mathrm{~s}, 1 \mathrm{H}, \mathrm{C}=\mathrm{C}-\mathrm{H}), 7.08-7.16 \\
(\mathrm{~d}, 2 \mathrm{H}, J=8.34 \mathrm{~Hz}), 7.44 \\
(\mathrm{~s}, 1 \mathrm{H}, \mathrm{C}=\mathrm{C}-\mathrm{H}), 7.25 \\
(\mathrm{~s}, 1 \mathrm{H}, \mathrm{Ar}-\mathrm{H}), 7.18-6.97 \\
(\mathrm{~d}, 1 \mathrm{H}, J=8.28 \mathrm{~Hz}), 4.09 \\
\left(\mathrm{~s}, 3 \mathrm{H},-\mathrm{OCH}_{3}\right)\end{array}$ & $\begin{array}{l}167.42(\mathrm{C}=\mathrm{O} \text {, thiazolidin-4-one), } \\
164.13(\mathrm{C}=\mathrm{N}, 2 \text {-ylidene carbon), } \\
156.62(\mathrm{C}=\mathrm{N} \text { of thiazolidinone), } \\
150.57,136.82,133.56,132.62, \\
129.65,127.94(\mathrm{C}-\mathrm{H}, \text { benzylidene } \\
\text { carbon }), 126.97,125.04(\mathrm{C}-5 \text { of } \\
\text { thiazolidinone), } 123.41,79.64, \\
79.41,79.19,56.34\left(-\mathrm{OCH}_{3}\right)\end{array}$ \\
\hline
\end{tabular}

a considerable decrease in the catalase activities $(p<0.05)$. A slight decrease in SOD and GPx activity was also obtained was not statistically significant $(p>0.05)$. The decreased activities of the serum antioxidant enzymes play an important role in scavenging the toxic intermediates of incomplete oxidation. 
Table 4: Changes in SOD, CAT, and GPx of normal and diabetic rats after 21 days of treatment with 10a-b and 4c TZD derivative

\begin{tabular}{llll}
\hline $\begin{array}{l}\text { Experimental } \\
\text { group }\end{array}$ & $\begin{array}{l}\text { SOD(u/mg } \\
\text { protein) }\end{array}$ & $\begin{array}{l}\text { CAT(mm H2O2 } \\
\text { decomposed/min) }\end{array}$ & $\begin{array}{l}\text { Gpx(u/mg } \\
\text { protein) }\end{array}$ \\
\hline Normal control & $2.24 \pm 0.01$ & $21.175 \pm 1.325$ & $30.71 \pm 2.93$ \\
Diabetic control & $1.46 \pm 0.015$ & $18.35 \pm 1.42$ & $35.30 \pm 2.37$ \\
Diabetes+ & $1.77 \pm 0.02$ & $17.42 \pm 1.55^{*}$ & $40.84 \pm 2.73$ \\
Rosiglitazone & & & \\
Diabetes+4b & $2.035 \pm 0.003^{*}$ & $16.98 \pm 1.63$ & $54.59 \pm 1.78$ \\
Diabetes+4d & $2.20 \pm 0.048^{*}$ & $19.30 \pm 1.34^{*}$ & $57.50 \pm 1.85^{*}$ \\
Diabetes+4c & $1.98 \pm 0.04^{*}$ & $20.30 \pm 1.13$ & $29.50 \pm 1.94^{*}$ \\
\hline
\end{tabular}

SOD: Superoxide dismutase; CAT: Catalase; GPx: Glutathione peroxidase. *Each value is mean $\pm \operatorname{SEM}(\mathrm{n}=6) ;{ }^{*} \mathrm{p}<0.01$ when compared to the day 1 values of the same group

\section{CONCLUSION}

Our research shows that p.o administration of 5-naphthylidene thiazolidinediones derivatives is an alternative treatment for IDDM, through the rejuvenation of $\beta$ cells of pancreas to stimulate insulin and other probable mechanism is they act as PPAR $\gamma$ agonist. The phenolic moiety present endowed significant oxygen free-radical scavenging activity.

\section{ACKNOWLEDGMENTS}

I sincerely thank Management and Dr. V. Murugan, Dean, College of Pharmaceutical Sciences, Dayananda Sagar University, Kumaraswamylayout, Bengaluru, for providing me an opportunity to embark on this project. I extend my thanks to Dr. Ashutosh Das and Dr. Saravanan, CRD section, PRIST University, Thanjavur, for their continuous support.

\section{AUTHORS' CONTRIBUTIONS}

All the authors have equal contribution for the manuscript preparation, and especially edited and the final copy was revised by Dr. Chandrashekhar and Dr. Asif.

\section{CONFLICTS OF INTEREST}

The authors declared that they have no conflict of interest.

\section{AUTHORS' FUNDING}

Not applicable.

\section{REFERENCES}

1. Pulok K, Kuntal M, Peter J, Mukherji K. A review on leads from Indian medicinal plants with hypoglycemic potentials. J Ethnopharmacol 2006; 106:1-28.

2. Chici P, Mokoagow MI, Kshanti AM, Soewondo P. The risk factors of inpatient hypoglycemia: A systematic review. Heliyon 2020;6:1-10.

3. Mohammad S, Ramesh B. Synthesis, characterization of 2, 4 -thiazolidinedione derivatives and evaluation of their antioxidant activity. J Drug Deliv Ther 2013;3:96-101.

4. Giacco F, Brownlee M. Oxidative stress and diabetic complications. Circ Res 2010;107:1058-70.

5. Sabiu S, O’Neill FH, Ashafa AO. Kinetics of $\alpha$-amylase and $\alpha$-glucosidase inhibitory potential of Zea mays Linnaeus (Poaceae), Stigma maydis aqueous extract: An in vitro assessment. J Ethnopharmacol 2016;183:1-8.

6. Tanga W, Lia S, Liub Y, Huang MT, Ho CT. Anti-diabetic activity of chemically profiled green tea and black tea extracts in a Type 2 diabetes mice model via different mechanisms. J Func Foods 2013;5:1784-937.

7. Chandrashekhara S. Kalpana D, Rekha S. Thiazolidin-4-one derivatives on human lung fibroblast shows oxygen free radical scavenging activity. Int Res J Pharm 2020;11:1-9.

8. Jain A, Pramodkumar PG. In silico comparative molecular docking study and analysis of glycyrrhizin from Abrus precatorius (L.) against antidiabetic activity. Eur J Med Plants 2015;6:212-22.

9. Cheng KH, Fu YC, Rong SL, Moon JY. iGEMDOCK: A graphical environment of enhancing GEMDOCK using pharmacological interactions and post-screening analysis. BMC Bioinf 2011;12:33-6.

10. Hassan Z, Yam MF, Ahmad M, Yusof PA. Antidiabetic properties and mechanism of action of Gynura procumbens water extract in streptozotocin-Induced diabetic rats. Molecules 2010;15:908-23.

11. Rekha S, Chandrashekhara S. In silico proportional molecular docking study and analysis of insulinotropic activity of TZD derivatives by PPAR $\gamma$ activation. J Pharma Sci Res 2017;9:1799-808.

12. Arpita K, Sriram PS, Subramanian S. Evaluation of antidiabetic and antioxidant activity of Praecitrullus fistulosus fruits in STZ induced diabetic rats. Res J Pharm Tech 2014;7:196-203.

13. Vidyasabbani, Ramesh A, Shobharani S. Comparative in vitro antidiabetic and antioxidant activity of Pulicaria wightinia, Curcuma inodora, Derris scandens leaf extracts. Res J Pharm Technol 2017;10:1615-20.

14. David AN, Welsh M, Casadaban MJ, Steiner DF. Control of insulin gene expression in pancreatic $\beta$-cells and in an insulin-producing cell line, RIN-5F Cells. J Biol Chem 1985;260:13585-9.

15. Al Nahdi AM, Annie J, Haider R. Elucidation of molecular mechanisms of streptozotocin-induced oxidative stress, apoptosis, and mitochondrial dysfunction in Rin-5F pancreatic $\beta$-cells. Oxid Med Cell Long 2017;7:1-15

16. Parka JH, Cho K, Nam H, Choe NH, Suh JG. Anti-apoptotic effects of silk fibroin hydrolysate in RIN5F cell on high glucose condition. Anim Cells Syst 2015;19:201-7.

17. Sepehr KS, Baradaran B, Mazandarani M, Khori V, Shahneh FZ. Studies on the cytotoxic activities of Punica granatum L. var. spinosa (Apple Punice) extract on prostate cell line by induction of apoptosis. ISRN Pharm 2012;547942:1-6.

18. Lokhande VY, Yadav AV. In vitro antioxidant and antidiabetic activity of supercritical fluid extract of leaves Ocimum sanctum L. Res J Pharm Technol 2018;11:5376-8

19. Ponnanikajamideen M, Rajeshkumar S, Annadurai G. In vivo antidiabetic and in vitro antioxidant and antimicrobial activity of aqueous leaves extract of Chamaecostus cuspidatus. Res J Pharm Technol 2016:9:1204-10.

20. Stockert JC, Castro AB, Cañete M, Horobin RB, Villanueva A. MTT assay for cell viability: Intracellular localization of the formazan product is in lipid droplets. Acta Histochem 2012;8:785-96.

21. McCord JM, Fridovich I. Superoxide Dismutase an enzymic function for erythrocuprein (hemocuprein). J Biol Chem 1969;22:6049-65.

22. Hadwan M, Khabt H. Simple spectrophotometric method for analysis of serum catalase activity. J Clin Diagn Res 2018;12:13-6.

23. Sarma BK, Mugesh G. Glutathione peroxidase (GPx)-like antioxidant activity of the organoselenium drug ebselen: Unexpected complications with thiol exchange reactions. J Am Chem Soc 2005; 127:11477-85.

24. Selvakumar D, Vijaya S. Design, synthesis and evaluation of vanillin semicarbazones as hypoglycemic agents in alloxan-induced diabetes in rats. J Pharm Res 2012;5:2441-2.

25. Arunachalam K, Thangaraj P. Antidiabetic and enzymatic antioxidant properties from methanol extract of Ficus talboti bark on diabetic rats induced by streptozotocin. Asian Pac J Reprod 2014;3:97-105. 